\title{
Is Percutaneous Endoscopic Gastrostomy (PEG) tube feeding Beneficial for Improving Survival in Patients with Dementia? A systematic review and meta- analysis of current evidences
}

\author{
Shima Raeesi \\ Tehran University of Medical Sciences \\ Rezvan Hashemi \\ Tehran University of Medical Sciences \\ Zahra Vahabi ( $\sim$ Vahab1357@gmail.com) \\ Tehran University of Medical Sciences \\ Mina Abdolahi \\ Tehran University of Medical Sciences \\ Mohsen Sedighiyan \\ Tehran University of Medical Sciences
}

\section{Research article}

Keywords: Dementia, Mortality, Survival, Nutrition support, PEG, Meta-analysis

Posted Date: December 2nd, 2019

DOI: https://doi.org/10.21203/rs.2.18110/v1

License: (1) This work is licensed under a Creative Commons Attribution 4.0 International License. Read Full License 


\section{Abstract}

Background Dementia is a progressive disabling neurogenic disease resulted in serious nutritional deficiencies included dysphagia, malnutrition and weight loss. The Percutaneous Endoscopic Gastrostomy (PEG) which is a long-term enteral feeding method that routinely use in demented patients with poor food intake as a standard protocol. However, most of the evidences have not shown beneficial effects of PEG feeding on complications or survival rates in these patients. Some studies have even reported an increase in mortality. The current systematic review and meta-analysis aimed to evaluate the mortality rate and survival in primary demented patients with PEG.Methods A systemically search conducted on Pubmed and Scopus databases up to Aug 2019 without language restriction. The data were reviewed according to Cochrane handbook and preferred reporting items for systematic reviews and meta-analyses (PRISMA) and meta-analysis of observational studies in epidemiology (MOOSE). Based on random-effects model, mortality rate and median survival were expressed as risk ratio and weighted mean difference (WMD) and 95\% $\mathrm{Cl}$ respectively.Results Among 13 included studies, PEG insertion in patients with primary dementia has no significant effect on 30-day, 90-day, 180-day, 1-year and 2-year mortality rate or median survival (WMD: 9.77; 95\% Cl: -22.43 to $41.98 ; P=0.55$ ). It seems that naso-gastric tube (NGT) feeding in compared to PEG in this population is more effective.Conclusion Further prospective studies are needed to comprehensive evaluation of mortality or survival regarding to comorbidities, underlying disease, cognitive and physical performance and nutritional problems in demented patients.

\section{Background}

Dementia is a progressive disabling neurogenic disease, derived from neurons damage in the brain (1). The patients with dementia often need hospitalization care which exert a lot of costs on the medical system (2). Dementia often lead to serious nutritional deficiencies because the patients with dementia are progressively losing their ability to chewing, swallowing or in advanced stage, even they cannot recognize food or eating components $(3,4)$ resulted in dehydration, malnutrition and weight loss $(5)$.

In dementia patients with nutritional problem, percutaneous endoscopic gastrostomy (PEG) usually is inserted although its beneficial effects are unclear (6). On the basis of evidences, the PEG which is a long-term enteral feeding method of administration, can improve nutritional status in patients with inadequate intake in neurogenic disorders (7). In papulation with dementia, while the PEG feeding tube placement is accepted as a standard care method in many health professionals, the evidences which evaluating the outcome of PEG feeding in dementia patients with poor food intake, malnutrition and who with nutritional difficulties reported no positive effects on survival rate (8). In the other hand, the most existing observation had revealed no harmful outcomes from PEG method usage in patients with dementia compared to in non-dementia patients (9).

In view of the contradictory effects of PEG insertion on survival as a routine method in dementia patients and regarding to limit data from previous evidences, the present study for the first time amid to perform a systematic review and meta-analysis of all relevant published studies to clarify the effects of PEG tube feeding on mortality rate and median survival in primary dementia patients.

\section{Methods}

\section{Literature screening and systematic search strategy}

The Preferred Reporting Items for Systematic Reviews and Meta-analysis (PRISMA) (10) and Meta-analysis of Observational Studies in Epidemiology (MOOSE) (11) instruction was used in present systematic review and meta-analysis. A systematically computerized search was performed on PubMed and SCOPUS up to Aug 2019 publications in English language. The Medical subject headings (MeSH) and non-MeSH key words used for search process were included Mental Disorders [Title/Abstract] OR Cognitive Dysfunction [Title/Abstract] OR Alzheimer Disease [Title/Abstract] OR Dementia [Title/Abstract] AND enteral feeding [Title/Abstract] OR gastrostomy [Title/Abstract] OR Percutaneous endoscopic gastrostomy [Title/Abstract] OR PEG [Title/Abstract]. The references section of all eligible articles as well as reviews or systematic reviews was checked manually to avoiding miss any related data. In next step, after importing relevant publication to the EndNote document management software (Clarivate Analytics), the duplicate data were detected and removed. We excluded laboratory studies (in vitro, in vivo or ex-vivo studies), animal studies, conference papers and review articles based on eligibility and exclusion criteria. The eligible studies were enrolled to this meta- analysis after review their abstract or full-text.

\section{Eligibility and Exclusion criteria}

At the present meta-analysis, we included the articles which met following eligibility criteria: I) The studies with full-text in English language II) Intervention with PEG as enteral tube feeding and III) The publications which reported sufficient information in the case of mortality rate and median survival at the intervention in PEG and control groups. 
The studies with any following defined exclusion criteria were excluded from our meta-analysis: I) laboratory research (in vitro, in vivo or ex-vivo) or animals studies, II) studies which not performed on elderly patients III) studies with no enough data about mortality rate and survival in demented patients with PEG or control group IV) Studies on effect of any other supplemental feeding method along with PEG in intervention group but not in control group and VI) Studies which had no control group.

\section{Data selection and extraction}

At the current systematic review and meta-analysis, the data from defined included studies, were extracted indecently by two reviewers (M.S. and M.A.). Any possible disagreement was solved after discussing or based on third reviewer (R.H.) consensus. In continue, following data extracted from all included studies: the first author name, the publication year, the country of study, the sample size, the design of studies, the gender of participants, mean age, the population type, the intervention feeding type, complications, risk ratio of 30day, 90-day, 180-day, 1-year and 2-year mortality as well as mean \pm standard deviation (SD) of median survival.

\section{Quality assessment}

The quality of observational studies was assessed according to the Newcastle-Ottawa Quality Assessment Scale included fallowing factors: I) Patient selection, II) comparability of the study groups, and III) assessment of outcome. Each study had a score of 0-9 and the studies that achieved six score or more stars considered as high quality (12) (Table 1).

\section{Statistical analysis}

At the current work, Review Manager 5.3.5 (The Nordic Cochrane Center, The Cochrane Collaboration) software was applied to data statistical analysis. The mortality rate (30-days, 90-days, 180-days, one-year and two-years mortality) as well as median survival days were considered as continuous variables and in continue, according random-effects model, mortality rate and median survival were expressed as risk ratio and weighted mean difference (WMD) and $95 \% \mathrm{Cl}$ respectively. The heterogeneity or homogeneity among included studies were identified based on Cochrane's $\mathrm{Q}$ test and $\mathrm{I}^{2}$ statistical test; If $\mathrm{P}<0.1$ and $\mathrm{I}^{2}>50 \%$, the study defined heterogeneous and If $\mathrm{P}>$ 0.1 and $\mathrm{I}^{2} \leq 50 \%$, the data accounted homogenous. In addition, the potential heterogeneity sources was detected by subgroup analyses (13) consist of disease, feeding method and age. It is necessary to mention, in the studies that the mortality rate was not available, we calculated mortality rates in groups using Kaplan-Meier graph and WebPlotDigitizer online software as well as the studies which median survival and range were not clarified $(13,14)$. Then, the median and rang were converted to mean and standard deviation according to method devised by Hozo et al (15). The $\mathrm{P}<0.05$ accounted as statistically significant in analysis.

\section{Results}

\section{Literature search}

The flow diagram of publications in Figure 1, is illustrated according to the Quality of Reporting of Meta-analyses statements. Overall, 13 study were included at present systematic review and meta-analysis. Two articles reported mortality in dementia patients who had PEG feeding tube $(16,17), 10$ studies reported survival rate (18-27) and one reported both of mortality rate and survival in this papulation (28).

At the primary databases searching, 11377 related data were identified (762 in PubMed and 10610 in Scopus). In continue, fallowing manual search of related articles, 5 additional studies were enrolled in the present systematic review and meta-analysis. In next step, the duplicated studies were determined and removed using Endnote software $(n=742)$.

The title and abstract of remained publications (10635) were reviewed to determine included studies. The fallowing studies were excluded from this work (totally 10574):

Unrelated studies ( $n=7891)$, the disorder other than dementia (872), the Data from patients with dementia were combined with other diseases $(n=166)$, animal or in vitro studies $(n=1053)$, case reports (261) and review articles $(n=249)$. Sixty-one articles selected and their eligibility were evaluated exactly trough review their full-text. Finally, 13 articles included to meta-analysis after studies with the following characteristics were excluded (totally $n=48)$ : Full text not found $(n=5)$, non-english full-texts $(n=12)$, without expected outcomes $(n=15)$, 
PEG was administered in combination with naso-gastric tube (NGT) or other alternative nutrition ( $\mathrm{n}=8)$ and the data from patients with dementia were combined with other diseases $(n=8)$.

\section{Study characteristics}

The included studies characteristics are presented in Table 2. Based on search strategy in this mete-analysis, the relevant data were enrolled up to Aug 2019. A total of 1020 dementia patients who had PEG feeding tube, and 1296 patients in control group (408 demented patients with oral nutrition (ON) or NGT nutrition support, 678 patients with secondary dementia as a result of stroke with PEG and 210 patients with other disease and PEG nutrition support) participated in current meta-analysis. The mean age of participants were 78.5 years old. Among included studies, 3 studies were performed in United States $(16,19,21), 3$ studies in Japan (24, 26, 27), 2 studies in Israel (18, 22), 1 study in United Kingdom (17), 1 study in France (20), 1 study in Sweden (23), 1 study in Colombia (25) and 1 study in Italy (28). Across the eligible articles, eight studies reported survival or mortality rate in dementia patients with PEG feeding as illustrated in Kaplan-Meier graph or table, one reported only 180-day mortality and in 7 articles median survival days was extractable from the study text or Kaplan-Meier graph (16-28). All of studies were performed on both of male and female except one (21). The feeding method, underling disorder, complications and predictors of poor survival of participants are presented in Table 2 . In the 4 studies the complications were not mentioned $(19,23,26,28)$. In 8 articles age has been evaluated as a survival predictor $(17,18,20,22,23,26-28)$, albumin serum levels in 3 articles $(18,20,27)$ and 1 articles dementia stage $(21)$, in other included studies, various factors have been mentioned and in two studies it has not mentioned $(16,24)$. Six studies had prospective and 7 studies had retrospective design. A significant increase in mortality rate in dementia patients with PEG tube feeding was reported in 3 articles $(16,17,28)$, higher survival was observed in 3 studies $(18,23,24)$, while Rimon et al (22), Atencio et al (25) and Ticinesi et al (28) reported shorter survival in these patients. Five included articles found no significant differences in median survival in dementia patients who receive PEG in compare to control group $(19-21,26,27)$ (Table 2).

\section{The 30-day mortality in demented patients with PEG}

As presented in figure 2, the risk ratio preformed on 8 studies, showed PEG intervention had no statistically significant effect on 30 -day mortality (RR: $1.16 ; 95 \% \mathrm{Cl}$ : 0.59 to $2.28 ; \mathrm{P}=0.66)$. In addition, a significant heterogeneity was observed among studies $\left(\mathrm{I}^{2}=81 \%\right.$, $\mathrm{P}<0.001)$.

To identify the between study heterogeneity sources, subgroup analysis was conducted on control group intervention (oral, NGT or PEG), diseases, and age (Table 3). The subgroup analysis found that in 30-day mortality, the PEG method intervention in control group, as well as disease (dementia or other disorder), and $80>$ age was detected as the potential sources of heterogeneity. However, among these subgroups, no significant reduction in 30-day mortality was found after subgroup analysis based on feeding method, disease and age (Table 3).

\section{The 90-day mortality in demented patients with PEG}

The overall RR from 8 studies showed that PEG intervention exerts no significant reduction in 90-year mortality (RR: 1.13; $95 \%$ Cl: 0.60 to 2.16; $P=0.70)$, with a considerable between studies heterogeneity $\left(I^{2}=93 \%, P<0.001\right)$ (Figure 3 ). Subgroup analysis showed that $P E G$ intervention in control group, disease (dementia or other diseases) and age ( $80>$ or $80 \leq$ ) are considered as heterogeneity sources. Fallowing subgroup analysis based on feeding rout in control participants, a significant reduction in 90-day mortality was found in NGT group (RR: $0.51 ; 95 \% \mathrm{Cl}$ : 0.31 to $0.82 ; \mathrm{P}=0.005)$ and increasing in 90 -day mortality in oral feeding in (RR: $1.70 ; 95 \% \mathrm{Cl}$ : 1.06 to 2.74 ; $\mathrm{P}=0.03$ ) comparison with $\mathrm{PEG}$ receiving patients with dementia.

In addition, no significant differences in 90-day mortality was observed after subgroup analysis based on other diseases or age (Table 3).

\section{The 180-day mortality in demented patients with PEG}


According to figure 4 illustrated RR of PEG feeding on 180-day mortality rate in patients with dementia preformed on 9 studies (505 cases and 857 controls), PEG intervention exerts no statistically significant reduction on 180-day mortality rate (RR: $1.07 ; 95 \% \mathrm{Cl}: 0.75$ to 1.53 ; $\mathrm{P}=0.70)$. There was a significant heterogeneity among included studies $\left(\mathrm{I}^{2}=88 \%, \mathrm{P}<0.001\right)$. Fallowing subgroup analysis based on feeding rout, disease and age as identified heterogeneity sources, a significant reduction in 180-day mortality was observed in NGT receiving group (RR: $0.59 ; 95 \% \mathrm{Cl}: 0.43$ to $0.81 ; \mathrm{P}=0.001$ ) comparison with PEG intervention in patients with dementia. also, no significant differences in 180-day mortality was found after subgroup analysis based on other diseases or age (Table 3).

\section{The 1-year mortality in demented patients with PEG}

At the present meta-analysis, based on overall effect sizes of 8 included data, the PEG intervention had no significant effect on 1-year mortality reduction (RR: $1.01 ; 95 \% \mathrm{Cl}: 0.77$ to $1.33 ; \mathrm{P}=0.94$ ), with a considerable heterogeneity across enrolled studies $\left(\mathrm{I}^{2}=92 \%, \mathrm{P}<0.001\right)$ (Figure 5). After subgroup analysis, a significant reduction in 1-year mortality rate was detected in NGT receiving group (RR: 0.67; 95\% Cl: 0.46 to $0.97 ; \mathrm{P}=0.04$ ) comparison with PEG intervention in dementia patients (Table 3 ).

\section{The 2-year mortality in demented patients with PEG}

The overall effect sizes that preformed on 5 studies illustrated that PEG intervention couldn't exert any statistically significant differences on 2-day mortality rate in patients with dementia (RR: 1.02; 95\% Cl: 0.77 to 1.34; $P=0.91$ ) (Figure 6). As presented in figure 6, a significant between-studies heterogeneity was detected $\left(\mathrm{I}^{2}=96 \%, \mathrm{P}<0.001\right)$. After subgroup analysis, a significant reduction in 2 -year mortality rate was detected in NGT receiving group (RR: $0.63 ; 95 \%$ Cl: 0.50 to $0.79 ; P=<0.001$ ) comparison with PEG intervention in dementia patients (Table 3). In addition, in patients $80 \leq$ years, peg intervention significantly increases 2 -years mortality (RR: $1.46 ; 95 \%$ Cl: 1.21 to 1.75 ; $P<0.001)$.

\section{The median survival days in demented patients with PEG}

The figure 7 illustrated the WMD of median survival days in demented patients with PEG method. The overall effect from the randomeffect model that preformed on 7 studies showed PEG intervention had no statistically significant effect on patient's median survival (WMD: 9.77; $95 \% \mathrm{Cl}$ : -22.43 to $41.98 ; \mathrm{P}=0.55$ ) (Figure 7). In addition, no significant between studies heterogeneity was identified among included studies $\left(\mathrm{I}^{2}=0 \%, \mathrm{P}=0.48\right)$ (Table 4$)$.

\section{Discussion}

The current systematic review and meta-analysis included 13 studies and a total of 1020 participants in PEG group with dementia and 1296 participants in control group. The PEG intervention has no statistically significant effect on 30-day, 90-day, 180-day, 1-year and 2year mortality rate or median survival days in patients with dementia. In addition, in order to clarify the effect of PEG feeding method on mortality rate and survival in dementia patients, subgroup analyzes was performed based on age as $80>$ or $80 \leq$, control group disorders as dementia or other disease and feeding method in control group as oral, NGT or PEG. However, after subgroup analysis it is found that NGT intervention in compared to PEG in dementia patients can significantly reduce 90-day, 180-day, 1-year and 2-year mortality rate while oral intake significantly increased 90-day and 2-year mortality rate. Also, 2-yaer mortality significantly increased in patients $80 \leq$ years old.

The PEG has been considered as a long-term enteral feeding since the 1980s (29) which can reduce aspiration rate in compare to NGT can be used in patients who are expected to require antral feeding for more than $2-3$ weeks $(30,31)$. On the basis of evidences PEG insertion can increases serum albumin that it accounts a biomarker of nutritional status evaluation (32). The PEG method is well accepted in patients with neurological disease who have nutritional difficulty such as dysphagia (33). But PEG placement in dementia patients is conflicting. Dementia is usually associated with major nutritional problems such as eating, chewing, swallowing, etc., especially with progression of the disease which lead to inadequate intake, weight loss and serious malnutrition (2). So, these patients often need support nutrition. Despite contradictory evidences, at the moment, PEG insertion is prescribed by physicians in the majority of dementia cases since they can't intake adequate energy and proteins which may affects dementia progression (34). 
In the current systematic review and meta-analysis, in dementia patients, PEG intervention could not affect mortality rate at any time and even increased mortality risk ratio, although it was not statistically significant. These finding are parallel with the results of several trials which reported that mortality rate significantly increase in PEG receiving patients with dementia $(16,28)$. In this context, Sanders et al demonstrated that dementia patients with PEG had a lower prognosis, with a $54 \%$ mortality at 30 -day,78\% at 90 -day, $81 \%$ at 180 -day, and $90 \%$ at one-year (17). Also, similar to mortality results, the PEG insertion in dementia patients had exert no significant positive differences on median survival. The most of previous studies in the context of PEG intervention and survival confirm the present results (26, 27). Some studies found no association between PEG insertion and survival in dementia patients $(19,21)$ while Ticinesi et al $(2016)$ and Atencio et al (2015) reported a significantly shorter survival in the PEG group with dementia $(25,28)$. In contrast, a significant positive effects of PEG insertion on increasing survival in dementia patients have been demonstrated (18). However, the most of the prospective studies the PEG enteral nutrition is not associated with an improvement in nutritional status, course of disease or survival (6). In this context, Teno et al., in their large prospective cohort study in patients with dementia found no correlation between PEG and survival (35). Even, PEG method may be associated with higher risk of pressure ulcers as secondary adverse effects (36). Also, in other disorder with nutritional problems such as Amyotrophic lateral sclerosis no significant improvement in mortality or survival were observed (37).

In the current meta-analysis, we observed that NGT in compared to PEG in dementia patients can significantly reduce mortality rate. Although the results of studies in this area are conflicting, the majority of evidences did not observe significant effects on mortality or survival (18). A meta-analysis by Elke et al (2016) reported that in critically ill patients, the NGT had no effect on mortality rate but could decreases comorbidities (such as infectious complications or mechanical ventilation (38). Another study also, reported that the PEG insertion is more effective and safer compared to NGT, but no significant difference in mortality rates or adverse outcomes were observed (39). It seems that mortality or survival may depend more on nature and stage of disease, comorbidities and performance status which still poorly have been investigated (40).

In addition, our subgroup analysis found $80 \leq$ age as a strong predictor of 2-years mortality which is contrary to Ticinesi et al. results (28). Parallel with this, it has been observed that PEG insertion in patients before the age of 80 had significantly longer survival than others (41, 42). However, Further studies are needed to reach a definitive conclusion in this case. In this regard, to evaluate the effect of PEG feeding on mortality and survival and make a correct decision to apply in patients with dementia, further comprehensive evaluation of comorbidities, underlying disease, life style, cognitive and physical performance as well as nutritional problems should be conducted in older patients with advanced or not-advanced dementia.

The main limitation of the present study was that the control group was not homogeneous in terms of underlying diseases and the feeding method adjusted by subgrouping analysis. Another limitation was the limit number of studies in primary dementia condition. The majority of studies were performed in patients with secondary dementia derived from stroke or other disease. In addition, the stage of dementia was not mentioned in many studies which exert a considerable effect on prognosis of disease.

\section{Conclusions}

In conclusion, present systematic review and meta-analysis showed that PEG insertion in patients with primary dementia has no significant effect on mortality rate or median survival. It seems that NGT feeding in compared to PEG in this population is more effective in the context of reduction of mortality rate. Larger human studies with considering clinical, paraclinical and nutritional status as well as disease stage, etc., should be performed in primary dementia patients to clarify whether PEG feeding method can be effective in reducing mortality and increasing survival.

\section{Abbreviations}

NGT: Naso-gastric tube; ON: Oral nutrition; PEG: Percutaneous Endoscopic Gastrostomy

\section{Declarations}

\section{Ethics approval and consent to participate}

Not applicable

\section{Consent for publication}




\section{Availability of data and materials}

The data that support the findings of this study are available from Mina Abdolahi but restrictions apply to the availability of these data, which were used under license for the current study, and so are not publicly available. Data are however available from the authors upon reasonable request and with permission of Mina Abdolahi (m-abdolahi@razi.tums.ac.ir)

\section{Competing interests}

The authors declare that they have no competing interests.

\section{Funding}

None funding support

\section{Acknowledgements}

Present systematic review and meta-analysis were performed in Tehran University of Medical Sciences. Those who participated in this study are kindly acknowledged.

\section{Authors' contributions}

SHR designed the article and collated information; MS contributed to data extraction the data; MA analyzed the data. RH contribute to drafting manuscript. The study was conducted under supervision of ZV. The manuscript has been read and approved by all authors.

\section{References}

1. Alzheimer's A. 2015 Alzheimer's disease facts and figures. Alzheimer's \& dementia: the journal of the Alzheimer's Association. 2015;11(3):332.

2. Douglas JW, Lawrence JC, Turner LW. Social ecological perspectives of tube-feeding older adults with advanced dementia: A systematic literature review. Journal of nutrition in gerontology and geriatrics. 2017;36(1):1-17.

3. Sanders DS, Leeds JS, Drew K. The role of percutaneous endoscopic gastrostomy in patients with dementia. British Journal of Nursing. 2008;17(9):588-94.

4. Dunne A. Nutrition and dementia. Nursing and Residential Care. 2010;12(3):112-6.

5. Chung AM. Percutaneous gastrostomy feeding tubes in end stage dementia: don't "just do it". Canadian Association of Radiologists Journal. 2012;63(3):S5-S6.

6. Sampson EL, Candy B, Jones L. Enteral tube feeding for older people with advanced dementia. Cochrane database of systematic reviews. 2009(2).

7. Mazzini L, Corra T, Zaccala M, Mora G, Del Piano M, Galante M. Percutaneous endoscopic gastrostomy and enteral nutrition in amyotrophic lateral sclerosis. Journal of neurology. 1995;242(10):695-8.

8. Goldberg LS, Altman KW. The role of gastrostomy tube placement in advanced dementia with dysphagia: a critical review. Clinical interventions in aging. 2014;9:1733. 
9. Salomon ALR, Novaes MCG. Outcomes of enteral nutrition for patients with advanced dementia-A systematic review. The journal of nutrition, health \& aging. 2015;19(2):169-77.

10. Panic N, Leoncini E, De Belvis G, Ricciardi W, Boccia S. Evaluation of the endorsement of the preferred reporting items for systematic reviews and meta-analysis (PRISMA) statement on the quality of published systematic review and meta-analyses. PloS one. 2013;8(12):e83138.

11. Stroup DF, Berlin JA, Morton SC, Olkin I, Williamson GD, Rennie D, et al. Meta-analysis of observational studies in epidemiology: a proposal for reporting. Jama. 2000;283(15):2008-12.

12. Peterson J, Welch V, Losos M, Tugwell P. The Newcastle-Ottawa scale (NOS) for assessing the quality of nonrandomised studies in meta-analyses. Ottawa: Ottawa Hospital Research Institute. 2011.

13. Higgins JP, Green S. Cochrane handbook for systematic reviews of interventions: John Wiley \& Sons; 2011.

14. Dudley WN, Wickham R, Coombs N. An introduction to survival statistics: Kaplan-Meier analysis. Journal of the advanced practitioner in oncology. 2016;7(1):91.

15. Hozo SP, Djulbegovic B, Hozo I. Estimating the mean and variance from the median, range, and the size of a sample. BMC medical research methodology. 2005;5(1):13.

16. Nair S, Hertan H, Pitchumoni C. Hypoalbuminemia is a poor predictor of survival after percutaneous endoscopic gastrostomy in elderly patients with dementia. The American journal of gastroenterology. 2000;95(1):133.

17. Sanders DS, Carter M, D'silva J, James G, Bolton R, Bardhan K. Survival analysis in percutaneous endoscopic gastrostomy feeding: a worse outcome in patients with dementia. The American journal of gastroenterology. 2000;95(6):1472.

18. Dwolatzky T, Berezovski S, Friedmann R, Paz J, Clarfield A, Stessman J, et al. A prospective comparison of the use of nasogastric and percutaneous endoscopic gastrostomy tubes for long-term enteral feeding in older people. Clinical Nutrition. 2001;20(6):535-40.

19. Meier DE, Ahronheim JC, Morris J, Baskin-Lyons S, Morrison RS. High short-term mortality in hospitalized patients with advanced dementia: lack of benefit of tube feeding. Archives of Internal Medicine. 2001;161(4):594-9.

20. Paillaud E, Bories P-N, Merlier I, Richardet J-P, Jeanfaivre V, Campillo B. Prognosis factors of short and long-term survival in elderly hospitalized patients after percutaneous endoscopic gastrostomy. 2002.

21. Murphy LM, Lipman TO. Percutaneous endoscopic gastrostomy does not prolong survival in patients with dementia. Archives of Internal Medicine. 2003;163(11):1351-3.

22. Rimon E, Kagansky N, Levy S. Percutaneous endoscopic gastrostomy; evidence of different prognosis in various patient subgroups. Age and ageing. 2005;34(4):353-7.

23. Malmgren A, Hede GW, Karlström B, Cederholm T, Lundquist P, Wirén M, et al. Indications for percutaneous endoscopic gastrostomy and survival in old adults. Food \& nutrition research. 2011;55(1):6037.

24. Kumagai R, Kubokura M, Sano A, Shinomiya M, Ohta S, Ishibiki Y, et al. Clinical evaluation of percutaneous endoscopic gastrostomy tube feeding in Japanese patients with dementia. Psychiatry and clinical neurosciences. 2012;66(5):418-22.

25. Atencio DP, Blanco Pérez ÁG, Otero Regino W. Percutaneous Endoscopic Gastrostomy in elderly, indications, safety and outcomes. Revista Colombiana de Gastroenterologia. 2015;30(1):3-10.

26. Takayama K, Hirayama K, Hirao A, Kondo K, Hayashi H, Kadota K, et al. Survival times with and without tube feeding in patients with dementia or psychiatric diseases in Japan. Psychogeriatrics. 2017;17(6):453-9.

27. Tomioka H, Yamashita S, Mamesaya N, Kaneko M. Percutaneous endoscopic gastrostomy for aspiration pneumonia: A 10-year single-center experience. Respiratory investigation. 2017;55(3):203-11.

28. Ticinesi A, Nouvenne A, Lauretani F, Prati B, Cerundolo N, Maggio M, et al. Survival in older adults with dementia and eating problems: To PEG or not to PEG? Clinical nutrition. 2016;35(6):1512-6.

29. Ponsky JL, Gauderer MW. Percutaneous endoscopic gastrostomy: indications, limitations, techniques, and results. World Journal of Surgery. 1989;13(2):165-70.

30. Löser C, Aschl G, Hebuterne X, Mathus-Vliegen E, Muscaritoli M, Niv Y, et al. ESPEN guidelines on artificial enteral nutritionpercutaneous endoscopic gastrostomy (PEG). Clin Nutr. 2005;24(5):848-61.

31. Loser C, Wolters S, Folsch U. Enteral long-term nutrition via percutaneous endoscopic gastrostomy (PEG) in 210 patients a four-year prospective study. Digestive diseases and sciences. 1998;43(11):2549-57.

32. Sarkar P, Cole A, Scolding NJ, Rice CM. Percutaneous endoscopic gastrostomy tube insertion in neurodegenerative disease: a retrospective study and literature review. Clinical endoscopy. 2017;50(3):270. 
33. Löser C. Clinical aspects of long-term enteral nutrition via percutaneous endoscopic gastrostomy (PEG). The journal of nutrition, health \& aging. 2000;4(1):47-50.

34. Delegge MH. Percutaneous endoscopic gastrostomy in the dementia patient: helpful or hindering? The American journal of gastroenterology. 2008;103(4):1018.

35. Teno JM, Gozalo PL, Mitchell SL, Kuo S, Rhodes RL, Bynum JP, et al. Does feeding tube insertion and its timing improve survival? Journal of the American Geriatrics Society. 2012;60(10):1918-21.

36. Teno JM, Gozalo P, Mitchell SL, Kuo S, Fulton AT, Mor V. Feeding tubes and the prevention or healing of pressure ulcers. Archives of internal medicine. 2012;172(9):697-701.

37. Yang B, Shi X. Percutaneous endoscopic gastrostomy versus fluoroscopic gastrostomy in amyotrophic lateral sclerosis (ALS) sufferers with nutritional impairment: A meta-analysis of current studies. Oncotarget. 2017;8(60):102244.

38. Elke G, van Zanten AR, Lemieux M, McCall M, Jeejeebhoy KN, Kott M, et al. Enteral versus parenteral nutrition in critically ill patients: an updated systematic review and meta-analysis of randomized controlled trials. Critical Care. 2016;20(1):117.

39. Gomes Jr CA, Andriolo RB, Bennett C, Lustosa SA, Matos D, Waisberg DR, et al. Percutaneous endoscopic gastrostomy versus nasogastric tube feeding for adults with swallowing disturbances. Cochrane database of systematic reviews. 2015(5).

40. Mitchell SL, Miller SC, Teno JM, Kiely DK, Davis RB, Shaffer ML. Prediction of 6-month survival of nursing home residents with advanced dementia using ADEPT vs hospice eligibility guidelines. Jama. 2010;304(17):1929-35.

41. McCARTHY M, ADDINGTON-HALL J, Altmann D. The experience of dying with dementia: a retrospective study. International journal of geriatric psychiatry. 1997;12(3):404-9.

42. Higaki F, Yokota O, Ohishi M. Factors predictive of survival after percutaneous endoscopic gastrostomy in the elderly: is dementia really a risk factor? The American journal of gastroenterology. 2008;103(4):1011.

\section{Tables}




\begin{tabular}{|c|c|c|c|c|c|c|c|c|c|}
\hline $\begin{array}{c}\text { Study } \\
\text { source }\end{array}$ & $\begin{array}{c}\text { Representativeness } \\
\text { of the exposed } \\
\text { cohort }\end{array}$ & $\begin{array}{l}\text { Selection } \\
\text { of the } \\
\text { non- } \\
\text { exposed } \\
\text { cohort }\end{array}$ & $\begin{array}{c}\text { Ascertainment } \\
\text { of exposure }\end{array}$ & $\begin{array}{c}\text { Demonstration } \\
\text { that outcome of } \\
\text { interest was not } \\
\text { present at start } \\
\text { of study }\end{array}$ & $\begin{array}{l}\text { Comparability } \\
\text { of cohorts on } \\
\text { the basis of } \\
\text { the design or } \\
\text { analysis }\end{array}$ & $\begin{array}{l}\text { Assessment } \\
\text { of outcome }\end{array}$ & $\begin{array}{c}\text { Was } \\
\text { follow-up } \\
\text { long } \\
\text { enough for } \\
\text { outcomes } \\
\text { to occur } \\
\text { (>= } \\
5 \text { years) }\end{array}$ & $\begin{array}{l}\text { Adequacy } \\
\text { of follow } \\
\text { up of } \\
\text { cohorts } \\
\text { (>80\%) }\end{array}$ & $\begin{array}{l}\text { Total } \\
\text { score }\end{array}$ \\
\hline $\begin{array}{c}\text { Nair et } \\
\text { al. } 2000\end{array}$ & 1 & 0 & 1 & 1 & 1 & 0 & 0 & 1 & 5 \\
\hline $\begin{array}{l}\text { Sanders } \\
\text { et al. } \\
2000\end{array}$ & 1 & 1 & 1 & 1 & 1 & 0 & 1 & 1 & 7 \\
\hline $\begin{array}{l}\text { Dwolatzky } \\
\text { et al. } \\
2001\end{array}$ & 1 & 1 & 1 & 1 & 1 & 0 & 1 & 1 & 7 \\
\hline $\begin{array}{l}\text { Meier et } \\
\text { al. } 2001\end{array}$ & 1 & 1 & 1 & 1 & 2 & 1 & 0 & 1 & 8 \\
\hline $\begin{array}{l}\text { Paillaud } \\
\text { et al. } \\
2002\end{array}$ & 1 & 1 & 0 & 1 & 1 & 0 & 0 & 1 & 5 \\
\hline $\begin{array}{l}\text { Murphy et } \\
\text { al. } 2003\end{array}$ & 1 & 1 & 1 & 1 & 1 & 0 & 1 & 1 & 7 \\
\hline $\begin{array}{c}\text { Rimon et } \\
\text { al. } 2005\end{array}$ & 1 & 1 & 0 & 1 & 1 & 0 & 1 & 1 & 6 \\
\hline $\begin{array}{l}\text { Malmgren } \\
\text { et al. } \\
2011\end{array}$ & 1 & 1 & 0 & 1 & 1 & 0 & 1 & 1 & 6 \\
\hline $\begin{array}{c}\text { Kumagai } \\
\text { et al. } \\
2012\end{array}$ & 1 & 1 & 0 & 1 & 2 & 0 & 1 & 0 & 6 \\
\hline $\begin{array}{c}\text { Atencio et } \\
\text { al. } 2015\end{array}$ & 1 & 1 & 1 & 1 & 1 & 0 & 1 & 1 & 7 \\
\hline $\begin{array}{c}\text { Ticinesi et } \\
\text { al. } 2016\end{array}$ & 0 & 1 & 0 & 1 & 2 & 0 & 1 & 1 & 6 \\
\hline $\begin{array}{l}\text { Takayama } \\
\text { et al. } \\
2017\end{array}$ & 1 & 1 & 1 & 1 & 2 & 0 & 1 & 0 & 7 \\
\hline $\begin{array}{c}\text { Tomioka } \\
\text { et al. } \\
2017\end{array}$ & 1 & 1 & 1 & 1 & 1 & 0 & 1 & 1 & 7 \\
\hline
\end{tabular}




\begin{tabular}{|c|c|c|c|c|c|c|c|c|c|c|}
\hline Author & Country & Design & $\begin{array}{l}\text { Dementia } \\
\text { group } \\
\text { disease } \\
\text { (n) }\end{array}$ & $\begin{array}{l}\text { Control group } \\
\text { disease (n) }\end{array}$ & $\begin{array}{c}\text { intervention } \\
\text { Dementia/ } \\
\text { control }\end{array}$ & $\begin{array}{l}\text { Gender } \\
\% \text { (M) }\end{array}$ & $\begin{array}{c}\text { Age } \\
\text { (y) }\end{array}$ & $\begin{array}{l}\text { Kaplan- } \\
\text { Meier } \\
\text { Survival } \\
\text { Analysis }\end{array}$ & $\begin{array}{l}\text { Complication } \\
\text { rate (n) }\end{array}$ & $\begin{array}{l}\text { Predictors } \\
\text { for Poor } \\
\text { Survival }\end{array}$ \\
\hline $\begin{array}{c}\text { Nair et } \\
\text { al. } 2000\end{array}$ & USA & Pros & $\begin{array}{c}\text { Dementia } \\
(55)\end{array}$ & $\begin{array}{c}\text { Other disease } \\
\text { (33) }\end{array}$ & PEG/ON & 29 & 82.2 & $\begin{array}{c}\text { Mortality at } \\
6 \text { months } \\
\text { was higher } \\
\text { in patients } \\
\text { who had a } \\
\text { PEG (44\% } \\
\text { vs } 26 \%, \mathrm{P}= \\
0.03) \text {. }\end{array}$ & $\begin{array}{c}\text { Fever (14), } \\
\text { Cellulitis (4), } \\
\text { Hemorrhage (1), } \\
\text { Ileus (1) }\end{array}$ & $\begin{array}{c}\text { Not } \\
\text { mentioned. }\end{array}$ \\
\hline $\begin{array}{l}\text { Sanders } \\
\text { et al. } \\
2000\end{array}$ & UK & Retro & $\begin{array}{l}\text { Dementia } \\
\text { (103) }\end{array}$ & $\begin{array}{c}\text { Stroke (120), } \\
\text { Oropharyngeal } \\
\text { malignancy } \\
\text { (65), } \\
\text { Miscellaneous } \\
\text { (73) }\end{array}$ & PEG/PEG & $\mathrm{NA}$ & 68.5 & $\begin{array}{l}\text { Dementia } \\
\text { group had a } \\
\text { worse } \\
\text { prognosis, } \\
\text { with a 54\% } \\
\text { mortality at } \\
1 \text { t } \\
\text { month, } 78 \% \\
\text { at } 3 \text { months, } \\
81 \% \text { at } 6 \\
\text { months, and } \\
90 \% \text { at } 1 \text { yr. }\end{array}$ & $\begin{array}{c}\text { Hemorrhage (6), } \\
\text { Peritonitis (3), } \\
\text { Pneumonia (97) }\end{array}$ & \begin{tabular}{|c} 
A Cox \\
proportional \\
hazards \\
statistical \\
analysis \\
showed that \\
age and \\
group were \\
independent \\
predictors \\
of mortality \\
(p \\
$<0.0001)$.
\end{tabular} \\
\hline $\begin{array}{l}\text { Dwolatzky } \\
\text { et al. } \\
2001\end{array}$ & Israel & Pros & $\begin{array}{l}\text { Dementia } \\
(32)\end{array}$ & Dementia (90) & PEG/NGT & 38 & 82.4 & $\begin{array}{c}\text { PEG group } \\
\text { was } \\
\text { significantly } \\
\text { higher } \\
\text { survival } \\
\text { rate than } \\
\text { those with } \\
\text { NGT, as } \\
\text { determined } \\
\text { by a } \\
\text { multivariate } \\
\text { cox } \\
\text { proportional } \\
\text { Hazard } \\
\text { model (P. } \\
0.006 ; \\
\text { HR.0.41; } \\
95 \% \text { CI; } \\
0.22-0.76) \text {. }\end{array}$ & $\begin{array}{l}\text { The data are } \\
\text { expressed as } \\
\text { hazard ratio. }\end{array}$ & $\begin{array}{c}\text { Albumin } \\
\text { (HR, 0.59; } \\
\text { 95\% CI 0.36 } \\
\text { - 1.96) } \\
\text { Age (HR, } \\
1.04 ; 95 \% \\
\text { CI 1.01 - } \\
1.08 \text { ) } \\
\text { Dementia } \\
\text { (HR, 1.4; } \\
\text { 95\% CI 0.77 } \\
\text { - 2.54) }\end{array}$ \\
\hline $\begin{array}{l}\text { Meier et } \\
\text { al. } 2001\end{array}$ & USA & Pros & $\begin{array}{c}\text { Advanced } \\
\text { dementia } \\
(68)\end{array}$ & $\begin{array}{c}\text { Advanced } \\
\text { dementia (31) }\end{array}$ & PEG/ON & 19 & 84 & $\begin{array}{c}\text { PEG was } \\
\text { not } \\
\text { associated } \\
\text { with } \\
\text { survival (P. } \\
\text { 0.9; } \\
\text { HR.0.97; } \\
\text { 95\% CI, 0.5- } \\
\text { 1.9). }\end{array}$ & Not mentioned. & \begin{tabular}{|c} 
Pneumonia \\
or urosepsis \\
(HR, 1.9; \\
95\% CI 1.0 \\
- 3.6) \\
Pressure \\
ulcer (HR, \\
1.07; 95\% \\
CI 0.6-1.8) \\
Dehydration \\
or \\
metabolic \\
abnormality \\
(HR, 1.6; \\
95\% CI 0.6 \\
- 4.3)
\end{tabular} \\
\hline $\begin{array}{l}\text { Paillaud } \\
\text { et al. } \\
2002\end{array}$ & France & Retro & $\begin{array}{c}\text { Dementia } \\
\text { (33) }\end{array}$ & $\begin{array}{c}\text { Without } \\
\text { dementia (40) }\end{array}$ & PEG/PEG & 32 & 82.6 & $\begin{array}{c}\text { PEG was } \\
\text { not } \\
\text { associated } \\
\text { with } \\
\text { survival } \\
\text { between } \\
\text { dementia } \\
\text { patient and } \\
\text { non- } \\
\text { demented } \\
\text { (P. 0.39). }\end{array}$ & $\begin{array}{c}\text { Pneumonia (39), } \\
\text { digestive disorders } \\
\text { (25), stomy } \\
\text { infection or } \\
\text { leakage } \\
\text { (14), abdominal } \\
\text { wall abscess (2), } \\
\text { pneumoperitoneum } \\
\text { (1). }\end{array}$ & \begin{tabular}{|c} 
Only patient \\
age (p \\
$<0.05)$, \\
patient \\
weight (p \\
$<0.04$ ), \\
presence of \\
pressure \\
sores (p \\
$<0.001)$, \\
and active \\
infection (p \\
$<0.001$ ) \\
were found \\
to have a \\
significant \\
effect on \\
survival. \\
Cancer, low \\
serum \\
albumin, \\
dementia, \\
underlying \\
disease and \\
male \\
gender \\
were not \\
identified as \\
predictors \\
of survival \\
in our study.
\end{tabular} \\
\hline $\begin{array}{l}\text { Murphy et } \\
\text { al. } 2003\end{array}$ & USA & Retro & $\begin{array}{c}\text { Dementia } \\
\text { (23) }\end{array}$ & Dementia (18) & PEG/ON & 100 & NA & \begin{tabular}{|c} 
There was \\
no \\
statistically \\
significant \\
difference \\
in survival \\
between the \\
groups (P. \\
o.37) using
\end{tabular} & $\begin{array}{c}\text { There was one } \\
\text { major complication } \\
\text { in the group that } \\
\text { underwent PEG, } \\
\text { complication rate } \\
\text { was } 4.3 \% \text {. }\end{array}$ & $\begin{array}{c}\text { despite a } \\
\text { bleak } \\
\text { prognosis } \\
\text { for survival } \\
\text { in patients } \\
\text { with } \\
\text { advanced } \\
\text { dementia } \\
\text { undergoing }\end{array}$ \\
\hline
\end{tabular}




\begin{tabular}{|c|c|c|c|c|c|c|c|c|c|c|}
\hline & & & & & & & & $\begin{array}{l}\text { the Kaplan- } \\
\text { Meier } \\
\text { survival } \\
\text { curve. }\end{array}$ & & $\begin{array}{l}\text { PEG, the } \\
\text { alternative } \\
\text { feeding - } \\
\text { would seem }\end{array}$ \\
\hline $\begin{array}{l}\text { Rimon et } \\
\text { al. } 2005\end{array}$ & Israel & Pros & $\begin{array}{c}\text { Dementia } \\
\text { (356) }\end{array}$ & $\begin{array}{l}\text { Dysphagia due } \\
\text { to stroke (362) }\end{array}$ & $\begin{array}{l}\text { PEG/PEG } \\
\end{array}$ & 42 & 80.1 & $\begin{array}{c}\text { Dementia } \\
\text { group } \\
\text { median } \\
\text { survival } \\
\text { (days): } \\
\text { (223,95\% } \\
\text { CI,173-- } \\
\text { 309)- } \\
\text { Stroke } \\
\text { group } \\
\text { median } \\
\text { survival } \\
\text { (days): } \\
\text { (327,95\% } \\
\text { Cl, 247-507) }\end{array}$ & $\begin{array}{c}\text { Early } \\
\text { complications (11): } \\
\text { Infection, } \\
\text { Peritonitis, } \\
\text { Mortality, apnoea } \\
\text { Late complications } \\
\text { (176): } \\
\text { Self-extubation, } \\
\text { Local irritation, } \\
\text { Leakage, Tube } \\
\text { obstruction, } \\
\text { Hematemesis, } \\
\text { Buried bumper }\end{array}$ & 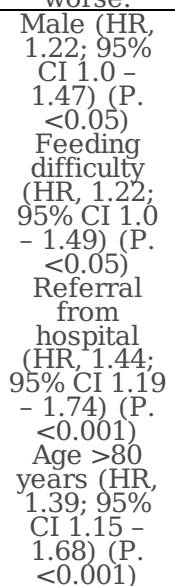 \\
\hline $\begin{array}{l}\text { Malmgren } \\
\text { et al. } \\
2011\end{array}$ & Sweden & Retro & $\begin{array}{l}\text { Dementia } \\
\text { (16) }\end{array}$ & Stroke (95) & PEG/PEG & 55 & 80.9 & $\begin{array}{c}\text { Patients } \\
\text { with } \\
\text { dementia } \\
\text { had the } \\
\text { longest } \\
\text { survival } \\
\text { while the } \\
\text { patients } \\
\text { with other } \\
\text { neurological } \\
\text { diseases. }\end{array}$ & Not mentioned. & $\begin{array}{l}\text { there was } \\
\text { no age- } \\
\text { related } \\
\text { difference } \\
\text { in the } \\
\text { various } \\
\text { diagnostic } \\
\text { subgroups } \\
\text { (data not } \\
\text { shown). }\end{array}$ \\
\hline $\begin{array}{l}\text { Kumagai } \\
\text { et al. } \\
2012\end{array}$ & Japan & Pros & $\begin{array}{c}\text { Dementia } \\
(151)\end{array}$ & Dementia (106) & PEG/NGT & 53 & 79.2 & $\begin{array}{l}\text { The survival } \\
\text { rate of the } \\
\text { PEG ogroup } \\
\text { (solid line) } \\
\text { is } \\
\text { significantly } \\
\text { higher by } 27 \\
\text { months than } \\
\text { that of the } \\
\text { NG t group } \\
\text { (P. 0.019). }\end{array}$ & $\begin{array}{c}\text { Aspiration } \\
\text { pneumonia: PEG } \\
\text { (36, p.<0.01), } \\
\text { NGT (54, p. 1.00) }\end{array}$ & $\begin{array}{c}\text { Not } \\
\text { mentioned. }\end{array}$ \\
\hline $\begin{array}{l}\text { Atencio et } \\
\text { al. } 2015\end{array}$ & Colombia & Retro & $\begin{array}{c}\text { Dementia } \\
\text { (29) }\end{array}$ & $\begin{array}{c}\text { Strokes and } \\
\text { other causes } \\
(67)\end{array}$ & PEG/PEG & 39.5 & 77.5 & $\begin{array}{l}\text { patients } \\
\text { who } \\
\text { underwent } \\
\text { PEG for } \\
\text { reasons } \\
\text { other than } \\
\text { dementia } \\
\text { had } \\
\text { significant } \\
\text { better } \\
\text { survival } \\
\text { times than } \\
\text { those who } \\
\text { underwent } \\
\text { PEG for } \\
\text { reasons } \\
\text { associated } \\
\text { with } \\
\text { dementia. }\end{array}$ & $\begin{array}{l}\text { Serious: Buried } \\
\text { Bumper } \\
\text { (9), fistula (1) } \\
\text { Minor: } \\
\text { diarrhea } \\
\text { distension (31), } \\
\text { Stoma infection } \\
\text { (10), Bleeding (4), } \\
\text { Changes of } \\
\text { Feeding Tube (23) }\end{array}$ & $\begin{array}{l}\text { the } \\
\text { probability } \\
\text { of diving } \\
\text { after PEG is } \\
\text { three times } \\
\text { greater for } \\
\text { patients } \\
\text { whose } \\
\text { indication } \\
\text { for the } \\
\text { procedure } \\
\text { was a } \\
\text { swallowing } \\
\text { disorder } \\
\text { associated } \\
\text { with } \\
\text { dementia } \\
(\mathrm{P} .<0.001) \text {. }\end{array}$ \\
\hline $\begin{array}{l}\text { Ticinesi et } \\
\text { al. } 2016\end{array}$ & Italy & Pros & $\underset{(54)}{\text { Dementia }}$ & Dementia (103) & PEG/ON & 31.5 & 82.2 & $\begin{array}{c}\text { Mortality } \\
\text { was higher } \\
\text { in PEG than } \\
\text { in ON group } \\
\text { (70\% vs } \\
40 \%, \text { p }< \\
0.001) . \\
\text { Survival } \\
\text { was } \\
\text { significantly } \\
\text { shorter in } \\
\text { the PEG } \\
\text { group (p< } \\
0.001)\end{array}$ & Not mentioned. & 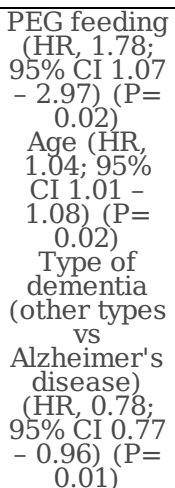 \\
\hline $\begin{array}{l}\text { Takayama } \\
\text { et al. } \\
2017\end{array}$ & Japan & Retro & $\begin{array}{c}\text { Dementia } \\
(42)\end{array}$ & Dementia (60) & PEG/NGT & 40 & 75.4 & $\begin{array}{c}\text { A log-rank } \\
\text { test did not } \\
\text { show a } \\
\text { sonificicant } \\
\text { difference } \\
\text { in survival } \\
\text { times of } \\
\text { dementia } \\
\text { patients } \\
\text { with PEG }\end{array}$ & Not mentioned. & $\begin{array}{l}\text { PEG (HR, } \\
0.53 ; 95 \% \\
\text { CI } 0.30 \% \\
0.94)(\mathrm{P}= \\
0.03) \\
\text { Age }(\mathrm{HR}, \\
1.04 ; 95 \% \\
\mathrm{CI} 1.01 \% \\
1.077 \text { (P= } \\
0.008)\end{array}$ \\
\hline
\end{tabular}




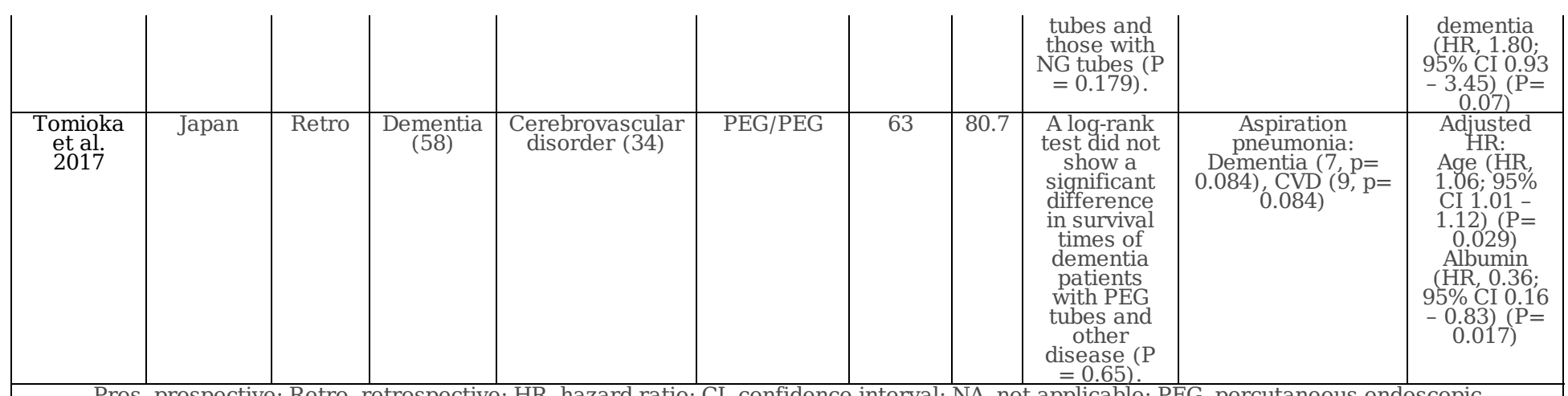

Pros, prospective; Retro, retrospective; HR, hazard ratio; CI, confidence interval; NA, not applicable; PEG, percutaneous endoscopic gastrostomy; ON, Oral Nutrition; NGT, nasogastric tube; CVD, Cerebrovascular disorder.

\begin{tabular}{|c|c|c|c|c|c|c|c|c|}
\hline \multirow[t]{2}{*}{ Subgroup heading } & \multirow[t]{2}{*}{ Outcome of interests } & \multirow[t]{2}{*}{ Subgroups } & \multirow[t]{2}{*}{ Number of studies } & \multirow[t]{2}{*}{$\mathrm{RR}(95 \% \mathrm{CI})$} & \multirow[t]{2}{*}{$P$ value } & \multicolumn{3}{|c|}{ Heterogeneity } \\
\hline & & & & & & $\chi^{2}$ & $\mathrm{I} 2, \%$ & $P$ value \\
\hline \multirow[t]{15}{*}{ Control group intervention } & \multirow[t]{3}{*}{ 30-days mortality } & NGT & 3 & $0.48(0.13,1.76)$ & 0.27 & 3.54 & 43 & 0.17 \\
\hline & & Oral & 2 & $1.52(0.85,2.72)$ & 0.16 & 0.27 & 0 & 0.60 \\
\hline & & PEG & 3 & $1.63(0.62,4.31)$ & 0.32 & 16.51 & 88 & $<0.001$ \\
\hline & \multirow[t]{3}{*}{ 90-days mortality } & NGT & 3 & $0.51(0.31,0.82)$ & 0.005 & 2.36 & 15 & 0.31 \\
\hline & & Oral & 2 & $1.70(1.06,2.74)$ & 0.03 & 2.11 & 53 & 0.15 \\
\hline & & PEG & 3 & $1.58(0.51,4.95)$ & 0.43 & 50.66 & 96 & $<0.001$ \\
\hline & \multirow[t]{3}{*}{ 180-days mortality } & NGT & 3 & $0.59(0.43,0.81)$ & 0.001 & 2.19 & 9 & 0.34 \\
\hline & & Oral & 3 & $1.58(0.96,2.60)$ & 0.07 & 8.26 & 76 & 0.02 \\
\hline & & PEG & 3 & $1.15(0.64,2.07)$ & 0.65 & 25.47 & 92 & $<0.001$ \\
\hline & \multirow[t]{3}{*}{ 1-year mortality } & NGT & 3 & $0.67(0.46,0.97)$ & 0.04 & 4.54 & 56 & 0.10 \\
\hline & & Oral & 2 & $1.39(0.613 .19)$ & 0.44 & 25.33 & 96 & $<0.001$ \\
\hline & & PEG & 3 & $1.11(0.65,1.91)$ & 0.69 & 62.73 & 97 & $<0.001$ \\
\hline & \multirow[t]{3}{*}{ 2-years mortality } & NGT & 2 & $0.63(0.50,0.79)$ & $<0.001$ & 0.05 & 0 & 0.82 \\
\hline & & Oral & 1 & $1.46(1.21,1.75)$ & $<0.001$ & - & - & - \\
\hline & & PEG & 2 & $1.22(0.67,2.23)$ & 051 & 136.9 & 99 & $<0.001$ \\
\hline \multirow[t]{10}{*}{ Control group disease } & \multirow[t]{2}{*}{ 30-days mortality } & Dementia & 5 & $0.88(0.38,2.04)$ & 0.77 & 10.00 & 60 & 0.04 \\
\hline & & Other diseases & 3 & $1.63(0.62,4.31)$ & 0.32 & 16.51 & 88 & $<0.001$ \\
\hline & \multirow[t]{2}{*}{ 90-days mortality } & Dementia & 5 & $0.91(0.45,1.86)$ & 0.80 & 26.52 & 85 & $<0.001$ \\
\hline & & Other diseases & 3 & $1.58(0.51,4.95)$ & 0.43 & 50.66 & 96 & $<0.001$ \\
\hline & \multirow[t]{2}{*}{ 180-days mortality } & Dementia & 5 & $0.92(0.55,1.55)$ & 0.76 & 28.92 & 86 & $<0.001$ \\
\hline & & Other diseases & 4 & $1.29(0.78,2.14)$ & 0.32 & 26.29 & 89 & $<0.001$ \\
\hline & \multirow[t]{2}{*}{ 1-year mortality } & Dementia & 5 & $0.94(0.60,1.46)$ & 0.78 & 40.02 & 90 & $<0.001$ \\
\hline & & Other diseases & 3 & $1.11(0.65,1.91)$ & 0.69 & 62.37 & 97 & $<0.001$ \\
\hline & \multirow[t]{2}{*}{ 2-years mortality } & Dementia & 3 & $0.85(0.43,1.69)$ & 0.64 & 37.15 & 95 & $<0.001$ \\
\hline & & Other diseases & 2 & $1.22(0.67,2.23)$ & 0.51 & 136.9 & 99 & $<0.001$ \\
\hline \multirow[t]{10}{*}{ Age (years) } & \multirow[t]{2}{*}{ 30-days mortality } & $80 \leq$ & 3 & $0.93(0.32,2.71)$ & 0.89 & 5.80 & 65 & 0.06 \\
\hline & & $80>$ & 5 & $1.33(0.54,3.27)$ & 0.54 & 27.50 & 85 & $<0.001$ \\
\hline & \multirow[t]{2}{*}{ 90-days mortality } & $80 \leq$ & 3 & $0.89(0.30,2.58)$ & 0.82 & 16.88 & 88 & $<0.001$ \\
\hline & & $80>$ & 5 & $1.31(0.55,3.11)$ & 0.54 & 74.35 & 95 & $<0.001$ \\
\hline & \multirow[t]{2}{*}{ 180-days mortality } & $80 \leq$ & 3 & $0.91(0.37,2.23)$ & 0.83 & 19.30 & 90 & $<0.001$ \\
\hline & & $80>$ & 6 & $1.15(0.76,1.74)$ & 0.52 & 46.10 & 89 & $<0.001$ \\
\hline & \multirow[t]{2}{*}{ 1-year mortality } & $80 \leq$ & 3 & $0.97(0.46,2.06)$ & 0.94 & 24.26 & 92 & $<0.001$ \\
\hline & & $80>$ & 5 & $1.03(0.74,1.43)$ & 0.88 & 66.97 & 94 & $<0.001$ \\
\hline & \multirow[t]{2}{*}{ 2-years mortality } & $80 \leq$ & 1 & $1.46(1.21,1.75)$ & $<0.001$ & - & - & - \\
\hline & & $80>$ & 4 & $0.92(0.67,1.27)$ & 0.62 & 83.37 & 96 & $<0.001$ \\
\hline
\end{tabular}




\begin{tabular}{|c|c|c|c|c|c|c|c|}
\hline \multirow[t]{4}{*}{ Subgroup heading } & \multirow{2}{*}{ Subgroups } & \multirow[t]{2}{*}{ Number of studies } & \multirow{2}{*}{ WMD (95\% CI) } & \multirow[t]{2}{*}{$P$ value } & \multicolumn{3}{|c|}{ Heterogeneity } \\
\hline & & & & & $\chi^{2}$ & $\mathrm{I} 2, \%$ & $P$ value \\
\hline & Oral & 2 & $31.12(-18.7,80.9)$ & 0.22 & 0.11 & 0 & 0.74 \\
\hline & PEG & 5 & $-7.63(-58.9,43.7)$ & 0.77 & 1.20 & 5 & 0.38 \\
\hline \multirow[t]{2}{*}{ Control group disease } & Dementia & 3 & $26.17(-22.5,74.9)$ & 0.29 & 1.00 & 0 & 0.61 \\
\hline & Other diseases & 4 & $-4.88(-78.8,69.0)$ & 0.90 & 3.75 & 20 & 0.29 \\
\hline \multirow[t]{2}{*}{ Age (years) } & $80 \leq$ & 5 & $-21.8(-109.9,66.2)$ & 0.63 & 4.03 & 1 & 0.40 \\
\hline & $80>$ & 2 & $14.75(-19.9,49.4)$ & 0.40 & 0.91 & 0 & 0.34 \\
\hline Total & - & 7 & $9.77(-22.4,41.9)$ & 9.77 & 5.53 & 0 & 0.48 \\
\hline
\end{tabular}

\section{Figures}

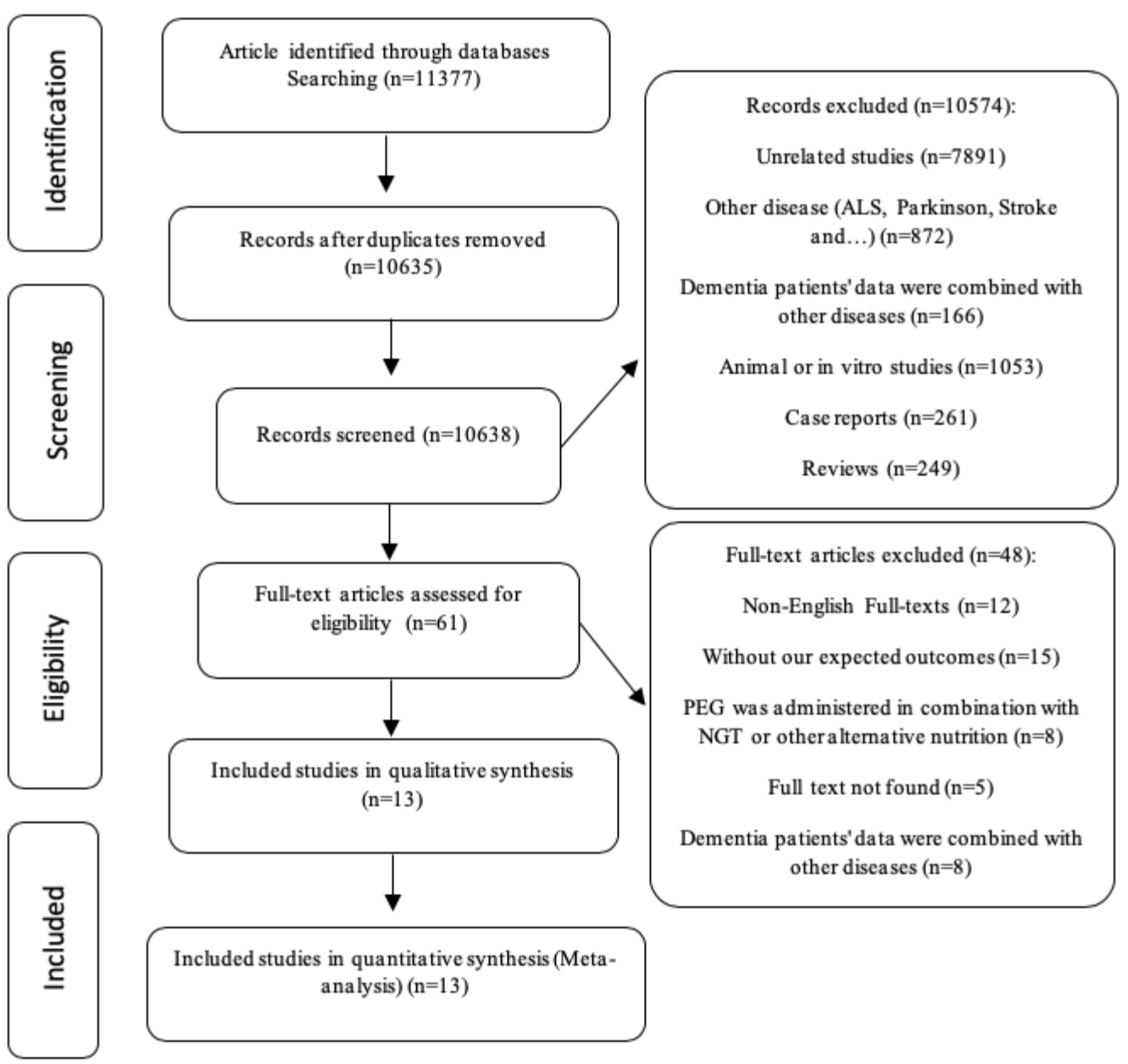

Figure 1

Flow diagram for the study selection 
$\begin{array}{llll}\text { PEG Control Risk Ratio } & \text { Risk Ratio }\end{array}$

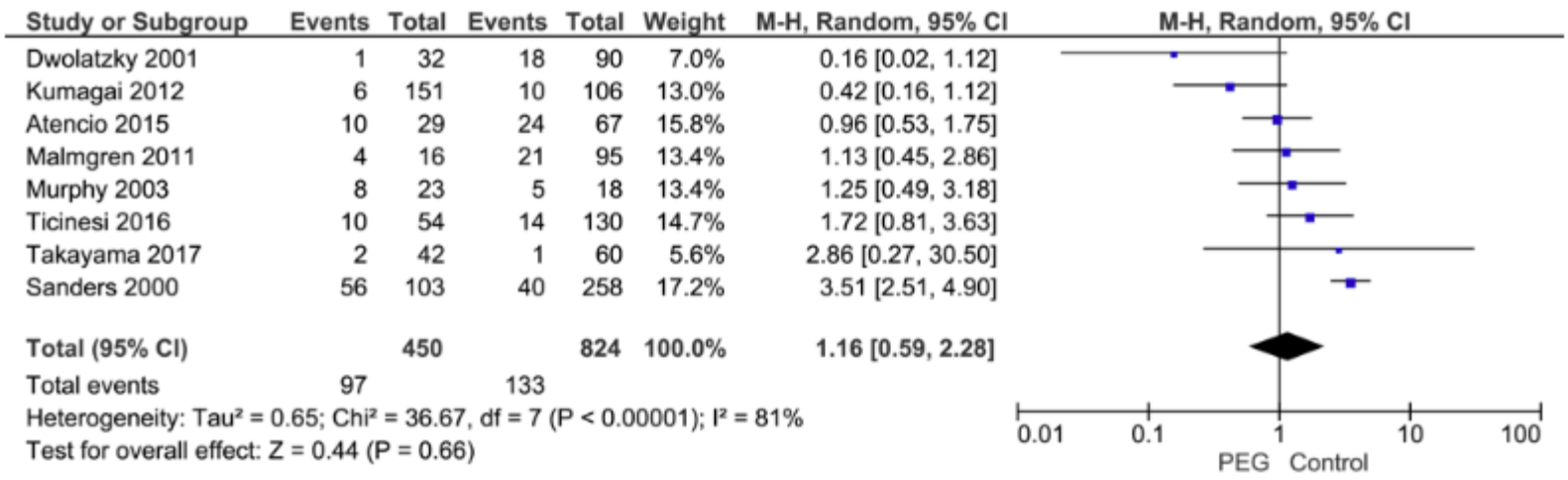

\section{Figure 2}

30-day mortality rate in demented patients with PEG feeding

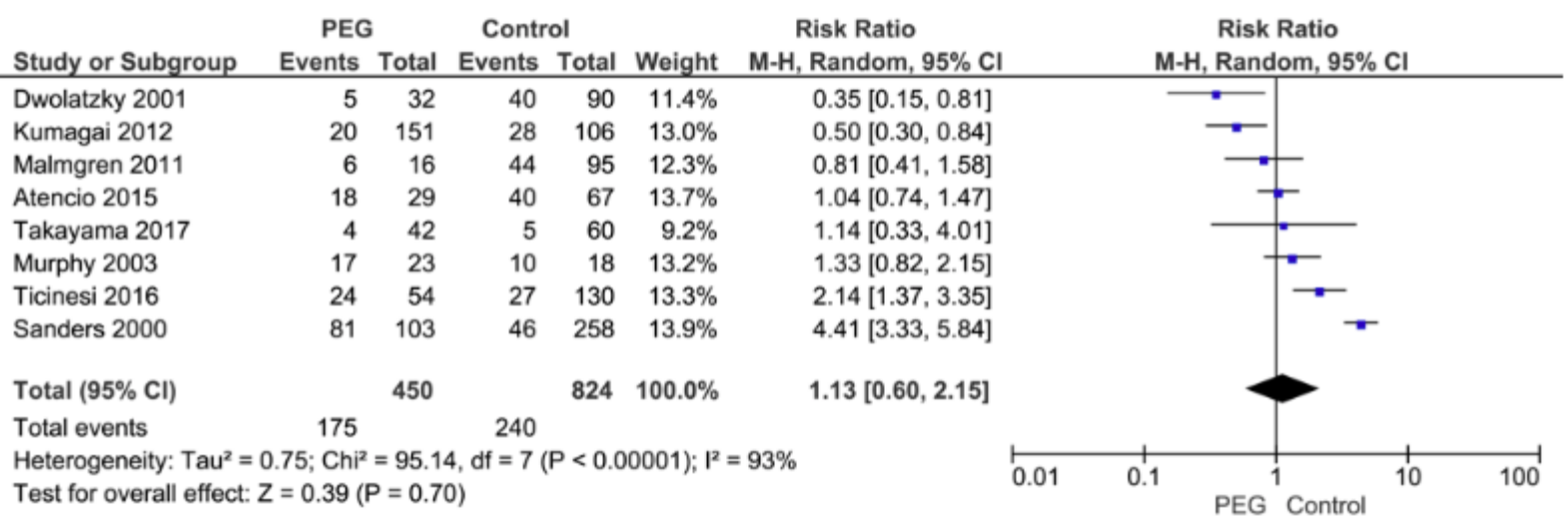

\section{Figure 3}

90-day mortality rate in demented patients with PEG feeding

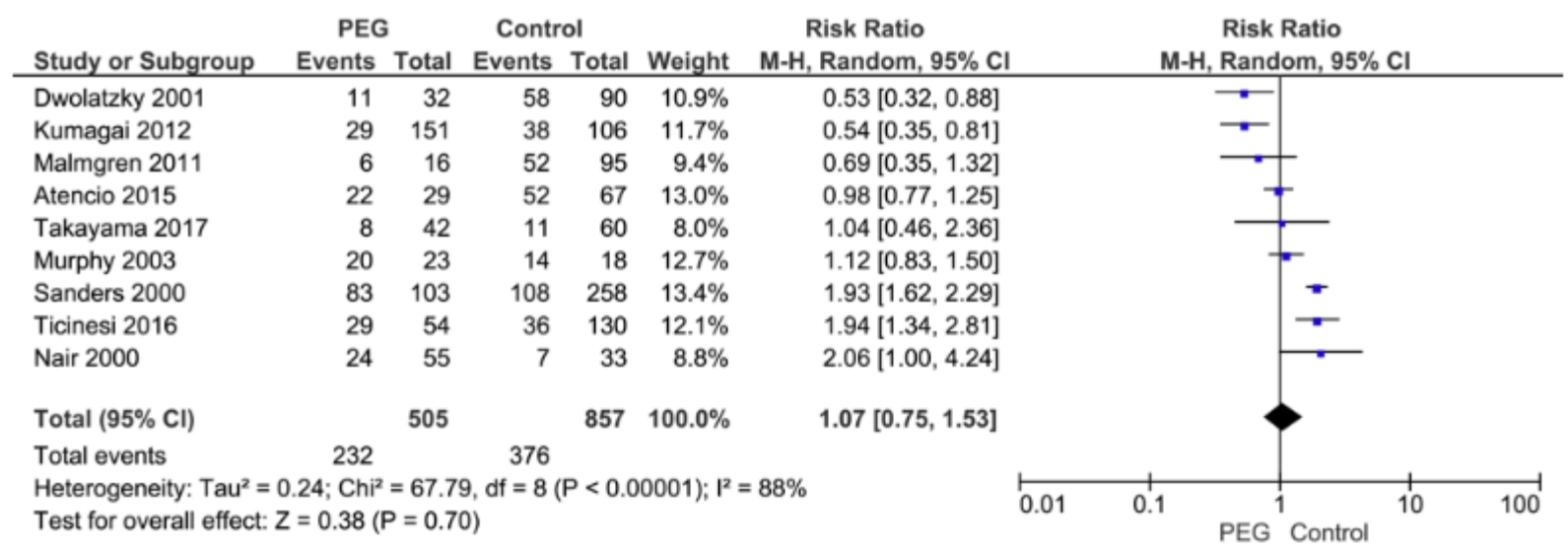

\section{Figure 4}

180-day mortality rate in demented patients with PEG feeding 


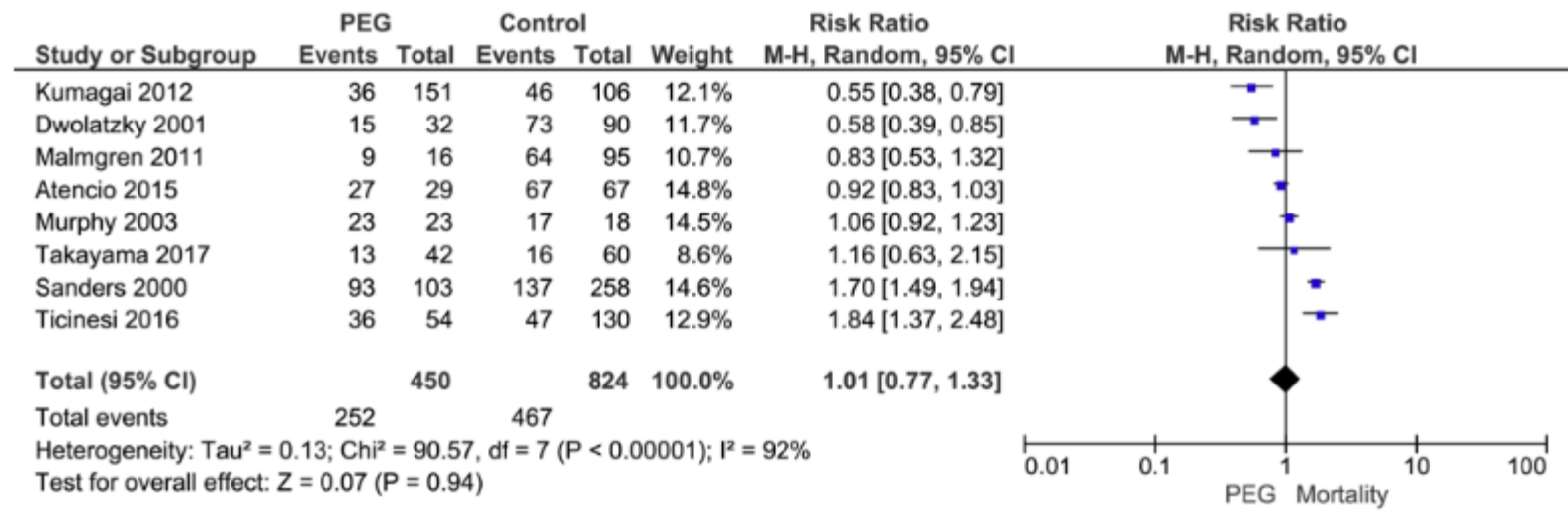

\section{Figure 5}

1-year mortality rate in demented patients with PEG feeding

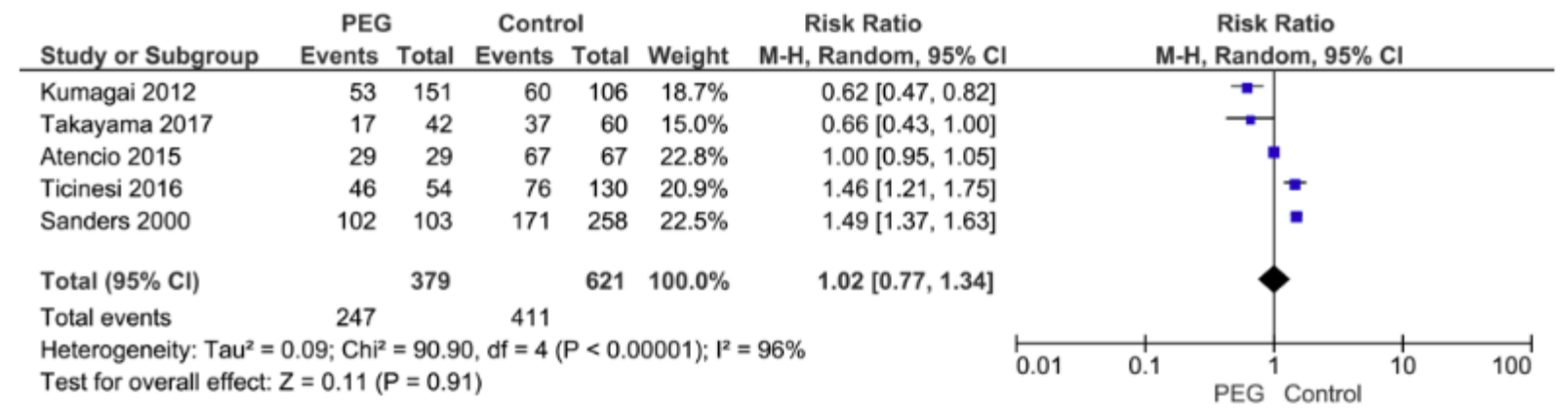

Figure 6

2-yaer mortality rate in demented patients with PEG feeding

\begin{tabular}{|c|c|c|c|c|c|c|c|c|c|c|c|}
\hline \multirow{2}{*}{ Study or Subgroup } & \multicolumn{3}{|c|}{ PEG } & \multicolumn{3}{|c|}{ Control } & \multicolumn{3}{|c|}{ Mean Difference } & \multirow{2}{*}{$\begin{array}{c}\text { Mean Difference } \\
\text { IV, Random, } 95 \% \mathrm{Cl} \text { [day] }\end{array}$} & \\
\hline & Mean [day] & SD [day] & Total & Mean [day] & SD [day] & Total & Weight & IV, Random, 95\% $\mathrm{Cl}$ [day] & & & \\
\hline Rimon 2005 & 223 & 652.3 & 356 & 327 & 1,258 & 362 & $4.8 \%$ & $-104.00[-250.24,42.24]$ & & $\longrightarrow$ & \\
\hline Paillaud 2002 & 130 & 274 & 33 & 215 & 699 & 40 & $1.9 \%$ & $-85.00[-320.93,150.93]$ & & & \\
\hline Atencio 2015 & 68 & 117.8 & 29 & 68 & 70 & 67 & $48.9 \%$ & $0.00[-46.03,46.03]$ & & 5 & \\
\hline Meier 2001 & 195 & 346 & 68 & 189 & 374 & 31 & $4.3 \%$ & $6.00[-149.23,161.23]$ & & & \\
\hline Murphy 2003 & 122 & 104.8 & 23 & 88 & 66 & 18 & $37.5 \%$ & $34.00[-18.57,86.57]$ & & 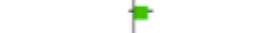 & \\
\hline Malmgren 2011 & 244 & 365 & 16 & 119 & 535 & 95 & $2.4 \%$ & $125.00[-83.71,333.71]$ & & 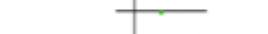 & \\
\hline Tomioka 2017 & 751 & 1,635 & 58 & 455 & 2,248 & 34 & $0.1 \%$ & $296.00[-568.88,1160.88]$ & & & \\
\hline Total $(95 \% \mathrm{Cl})$ & & & 583 & & & 647 & $100.0 \%$ & $9.77[-22.43,41.98]$ & & 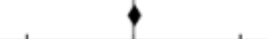 & \\
\hline $\begin{array}{l}\text { Heterogeneity: } \mathrm{Tau}^{2} \text { = } \\
\text { Test for overall effect: }\end{array}$ & $\begin{array}{l}.00 ; C h i^{2}=5 . \\
=0.59(P=0\end{array}$ & $\begin{array}{l}53, \mathrm{df}=6( \\
0.55)\end{array}$ & $P=0.4$ & $8) ; P=0 \%$ & & & & & -1000 & PEG ${ }^{0}$ Control 500 & 1000 \\
\hline
\end{tabular}

\section{Figure 7}

Median survival in demented patients with PEG feeding

\section{Supplementary Files}

This is a list of supplementary files associated with this preprint. Click to download.

- PRISMAchecklist.doc 